\title{
Towards a minimal conception of Transitional Justice
}

\author{
Valentina Gentile (D) and Megan Foster (D) \\ LUISS University, Roma, Italy \\ Author for correspondence: Valentina Gentile, E-mail: vgentile@luiss.it
}

(Received 21 July 2020; revised 8 March 2021; accepted 11 November 2021;

first published online 9 December 2021)

\begin{abstract}
Transitional Justice (TJ) focuses on the processes of dealing with the legacy of large-scale past abuses (in the aftermath of traumatic experiences such as war or authoritarianism) with the aim of fostering domestic justice and creating the basis for a sustainable peace. TJ however also entails the problem of how a torn society may be able to become a self-determining member of a just international order. This paper presents a minimal conception of TJ, which departs from Rawls' conception of normative stability of the international order, which suggests disentangling the two goals of fostering democracy within torn societies and TJ itself. The scope of TJ is therefore limited to enabling these societies to create minimal internal conditions for joining a just international order on equal footing. This paper makes an original contribution to two different debates, namely normative research on TJ, and post-Rawlsian literature in general. First, it provides a new direction for normative theorizing about $\mathrm{TJ}$ which takes both its domestic and international dimensions seriously into consideration. Second, it extends Rawls' political liberal outlook to an area where it is not usually understood to apply.
\end{abstract}

Key words: Duty of assistance; John Rawls; law of peoples; liberal democracy; normative stability; Transitional Justice

In the aftermath of traumatic experiences such as war or the fall of an authoritarian regime, societies are understandably fraught with divisions. In these deeply divided societies (hereafter, DDS) entrenched cleavages, especially along ethnic, religious, or other group lines are exacerbated by years of violence and turmoil which often give rise to further divides (e.g. victims vs. perpetrators). Often, historical factors, such as a colonial legacy, contribute to strengthen such old and new divisions. In DDS, Transitional Justice (hereafter TJ) refers to a process of coming to terms with the past that is strictly linked to that of creating the basis for some degree of peace and stability. A growing field of interdisciplinary research has evolved around this subject and examines the principles and policies best suited to aiding societies to confront their past and build the basis for their future.

\footnotetext{
(C) The Author(s), 2021. Published by Cambridge University Press. This is an Open Access article, distributed under the terms of the Creative Commons Attribution licence (http://creativecommons.org/licenses/by/4.0/), which permits unrestricted re-use, distribution and reproduction, provided the original article is properly cited.
} 
From a normative perspective, the project of $\mathrm{TJ}$ is linked to that of the creation of a new social order - one that ought to be able to combine some, at least, minimal conditions for domestic justice, and a durable/stable international peace. When these two things coincide, that is, when the social conditions support the forms of reciprocity necessary to facilitate the social cohesion from which institutions can emerge that effectively sustain international peace and respect for international law standards, ${ }^{1}$ we are in front of a form of stability which we might call normative as opposed to de facto stability. This paper suggests that a normative theory of TJ cannot be isolated from the problem of how DDS are able to (re-)build their own political structures so that they may autonomously manage their affairs and eventually become members in good standing of an ideally just, albeit plural, international society.

Thus, TJ has both domestic and international dimensions and the normative stability of both must be taken into account. This paper proposes a minimal conception of TJ, one that relies on a specific account of normative stability, namely Rawls' 'stability for the right reasons'. ${ }^{2}$ On this account, TJ should be minimal in two senses. First, it does not take democracy ${ }^{3}$ as the aim of the transition, but only as one possible outcome. Second, it should be considered as part of an amended version of the 'democratic peace thesis', one in which the stability 'for the right reasons' of a reasonably just international order might be endorsed not only by liberal regimes ${ }^{4}$ but also by those with other forms of political and economic organization, provided that they satisfy certain internal and external conditions. The processes and mechanisms of TJ should be therefore grounded in an extended ideal of international toleration that ought to govern the relations among sovereign states. Yet, allegiance to international law standards constitute the minimal political condition to recognize the "prima facie moral force ${ }^{5}$ of laws and institutions of selfdetermining, not necessarily liberal, political regimes. This paper makes a unique contribution to two different scholarly debates, namely normative scholarship on TJ, and Rawlsian scholarship in general. In terms of the former, we propose to show that the Rawlsian approach to ideal theorizing can provide a more attractive model than standard normative approaches. In terms of the latter, we intend to contribute to the literature by extending Rawls' theory to an area where it is not usually understood to apply.

The paper is divided into seven sections. Section one provides a hypothetical example of a DDS to set the parameters of the sort of problems we encounter in transitional contexts. Section two gives an overview of the normative issues raised

\footnotetext{
${ }^{1}$ In the paper, we use this expression to mean basic human rights and respect for International Law.

${ }^{2}$ Rawls 1996, xxxix, xl and 1999, 12-3.

${ }^{3} \mathrm{By}$ 'democracy', we mean those structures and procedures which aim to institutionalize popular sovereignty and some degree of political equality (see e.g. Dahl 1956).

${ }^{4}$ By liberal regimes, we mean those political entities based on core tenets of liberalism, such as constitutional and limited government, the rule of law, and individual freedoms, associated with democratic values such as the selection of government officials by universal suffrage, see Plattner 1999.

${ }^{5}$ See Reidy 2021, 24. These are the conditions that must be present in order for a regime to be considered 'decent' in Rawls's scheme, for a discussion about the conditions of decency see also Bernstein 2006. For an illuminating perspective on the possibility to include in the category of self-determining political regimes not only liberal but also nonliberal 'decent' peoples, see also Mandle 2020, 377ff.
} 
by TJ. Section three problematizes a prevailing view in the literature on this subject which considers democracy as the aim and metric of TJ. Section four presents our minimal conception and recasts the link between stability and justice in normative terms. To make this move, such a conception should be able to acknowledge the different scopes (domestic and international) of normative stability. Section five, therefore, builds on Rawls' political liberal outlook suggesting that this framework is uniquely suited for grasping the discontinuity between domestic and international justice. Section six considers TJ from the perspective of the threat to such a privileged form of stability. This perspective has important implications, as the minimal conception we propose is aimed at combining the objectives of international legitimacy and domestic well-orderedness. The concluding section confronts our minimal conception with actual cases of transition, exploring its practical possibilities, and stressing its normative attractiveness.

\section{Making sense of DDS}

Let's imagine a society which is just emerging from a long civil war. Like many DDS we encounter today, this society is a former colony of a European empire, whose practice of stoking differences along ethno-religious lines (or fabricating those when none existed) has led to hard-wrought cleavages. This society is now mainly comprised of members of two dominant clans whose mutual contempt was previously held precariously in check. Two general facts contribute to characterizing this society's emerging political culture. First, a neo-Marxist rhetoric becomes popular in light of the socio-economic grievances created by the prolonged foreign exploitation over the country's resources. Second, a traditional idea of the common good entailing continuity between spiritual and political hierarchies and an ideal of harmony as organizing principle shapes its social and political structures. ${ }^{6}$

Like in several DDS, the reconciliation process here presents a strong commitment to values and traditions grounded in the above-mentioned ideal of the common good. For example, traditional councils for reconciliation - resembling the bashingantahe in Burundi ${ }^{7}$ - and local courts - similar to the Gacaca courts in Rwanda $^{8}$ - are largely employed. The country is therefore moving in a more

\footnotetext{
${ }^{6} \mathrm{An}$ example of such a harmonizing principle is the Cameroonian concept of Chu (Wingo 2006). For a discussion about the role of neo-Marxism and communitarian values in post-colonial societies see Chemhuru 2018.

${ }^{7}$ Based on a precolonial practice, the bashingantahe were traditional mechanisms for conflict resolution largely employed in the first phase of post-conflict transition in Burundi until 2010, when a municipal law permanently excluded this practice. Although the social recognition of the bashingantahe declined in postcolonial Burundi, the values expressed by the bashingantahe, as both a traditional institution and an organizing principle, still persist in Burundi, see Ingalaere and Kohlahgen 2012, 47.

${ }^{8}$ The Gacaca court system was created in 2002 to offer more proximate and locally meaningful forms of justice. The courts are loosely rooted in the precolonial form of conflict mediation known as gacaca, which was traditionally used to settle minor local disputes, and has been substantially reimagined in order to handle the severity and volume of the disputes arising from the genocide. Recent scholarship has noted that some of the initial enthusiasm for the gacaca courts may have overlooked some serious flaws regarding their operation, including a general lack of institutional efficiency and a paucity of research into how the courts' outcomes impact the lives of ordinary people (Park 2010, Sharp 2013).
} 
peaceful direction, yet several features suggest that the transition might not be headed towards a liberal democratic order. The hierarchical and communitarian character of such traditional mechanisms raises doubts about the neutrality and transparency of the transitional process itself as well as the emerging political institutions. Furthermore, by emphasizing the need to prioritize socio-economic grievances over political and civil rights, the widely supported neo-Marxist values might orient the country's future economic and political organization in a nonliberal - perhaps strictly egalitarian - direction.

Let's imagine that the UN has just discovered a fool-proof scientific formula for aiding DDS through transitions. The process is so streamlined that a wellcoordinated army of aid-workers, development economists, political and civil society experts, and peacekeeping troops can change our society into a full democratic regime, practically overnight. Traditional councils and local courts are permanently excluded by a new State Law and replaced by a High Court with the twofold mandate of prosecuting war criminals and implementing the rule of law. A new constitution, which condemns both local traditions and the neo-Marxist values, is enacted. Our society is therefore well underway to becoming a full-fledged liberal democracy. The break-neck speed of the transition process means that the people had almost no time at all to internalize the changes in their political environment, and almost certainly remained unconvinced of their justification. The formula only works on institutions, not on the minds of people. Although our society now has all the trappings of a full-fledged liberal democracy, with well-functioning institutions to enshrine the freedom and equality of every citizen, one may reasonably have the uneasy feeling that this is not what justice requires in transition. In other words, while the state of affairs in the society might now be considered 'just', at least on a standard liberal view, on the same view it doesn't appear to be justifiable.'

This example, we believe, highlights the problem with standard normative approaches to TJ in DDS which seem to posit an unbreakable normative link between TJ and democracy. Yet, there might be an alternative, more promising way to construct the link between TJ and a certain understanding of liberal democracy, namely political liberalism, ${ }^{10}$ which still helps to determine what 'justice' requires in such transitions, without undermining the legitimate interest of a people in constructing a society that is uniquely their own. Recent works in the field of TJ have raised this problem in different ways. For some scholars, to impose a certain model of transition undermines already existing, more authentic, forms of social transformation within these societies. ${ }^{11}$ These concerns are amplified in light of the experience of colonial domination - an experience shared by most societies in which the need for TJ arises - where the imposition of a foreign, particularly Western model of political organization, harkens to the colonial past. ${ }^{12}$ Thus, scholars working in decolonial studies tend to confront TJ processes sceptically, especially when conceived as part of the standard liberal peace-building agenda. ${ }^{13}$ While we follow those scholars in their concerns, we stop short of abandoning

\footnotetext{
${ }^{9}$ See Bernstein 2006, 293.

${ }^{10}$ We follow Rawls in using this expression to denote the political liberal normative conception of authority, see Rawls 1996 and 1999.

${ }^{11}$ Rubli 2013.

${ }^{13}$ See, for example, Nagy 2008; De Sousa Santos 2015; Park 2020.
} 
the idea that international relations and TJ itself can be illuminated by some broadly shareable idea of (liberal) justice. With this in mind, we aim to lay out a theory of TJ that takes a critical distance from liberal peace-building, without generally abandoning certain core tenets of political liberalism itself.

\section{Towards a normative conception of TJ}

According to the UN Secretary-General, TJ encompasses 'the full range of processes and mechanisms associated with a society's attempts to come to terms with a legacy of large-scale past abuses, in order to ensure accountability, serve justice and achieve reconciliation'. ${ }^{14}$ Empirical research into the efficacy of various mechanisms aimed at supporting societies through the transition process and building stable and enduring regimes is complimented by normative inquiry into the morality, legitimacy, or overall normative fitness of said mechanisms. TJ has both forward- and backward-looking components: it combines an account of retributive and restorative justice with the twofold aim of (re)-establishing a minimum of rule of law and (re)building relationships within DDS. ${ }^{15}$ It might combine certain legal features, such as criminal prosecution for those responsible for gross violations, with 'restorative' instruments, such as amnesties and truth and reconciliation commissions (TRCs). It might also include memorials and other features aimed at keeping alive the memory of the past abuses.

Recently, what has been described as the 'fourth generation' of TJ is characterized in an increasing willingness - on the part of scholars and practitioners - to address issues that have historically sat at the periphery of TJ. ${ }^{16}$ The features which are gaining momentum are an increased reliance on local, community-based resources for accomplishing justice and the push to expand the definition of TJ to cover socio-economic justice as well. According to this view, TJ theories and practices cannot ignore the need to balance 'between local and international agency', ${ }^{17}$ nor overlook the importance of socio-economic factors in transitional contexts as these are often so deeply interconnected with the issues standardly associated with TJ (genocide, torture, and the systematic violation of other urgent rights) that it is nearly impossible to tease them apart.

The relationship between the various aspects of TJ is not always straightforward for example, the ends of retributive and restorative justice may come into conflict if amnesty is offered to criminals in exchange for testimony in TRCs - but the developments which have taken place in the context of the fourth generation complicate things even further. The increased reliance on local resources for accomplishing justice can force us to prioritize between local and international norms, just as the push for socio-economic justice might ask us to prioritize between political and economic rights. All of this can be quite difficult to bring under the rubric of TJ and it is vital that a theory considers context-specific social imaginaries -

\footnotetext{
${ }^{14}$ See Guidance Note of the Secretary-General 2010, 2.

${ }^{15} \mathrm{By}$ 'relationships' we mean not only interpersonal relationships but also social interactions (e.g. among members of different groups and communities) and political relations among citizens. As Murphy (2010) has shown, although transitional contexts are characterized by several forms of divisions which crosscut the public-private divide, the sort of political reconciliation DDS should aim to is one that entails all these dimensions.

${ }^{16}$ Sharp 2013, 149.

${ }^{17}$ Sharp 2013, 157.
} 
how people imagine their social existence together ${ }^{18}$ - as well as norms and principles.

A normative framework should help to evaluate the goals of the transitional process and weigh in on how the various components (TRCs, trials, community-based mechanisms, etc.) are justified, how they relate to one another and, should they appear to be at odds, provide a defensible metric for adjudicating between them. All these aspects are commonly tackled in normative literature as chiefly domestic issues, with TJ articulated in terms of moral standards for DDS as they cope with a legacy of past violence and restore disrupted relationships. Yet, TJ is also an important matter of international concern. The transition process is one societies rarely face alone: international actors, from other nations to IGOs and NGOs, provide military, financial, and institutional support during the transition process and its success or failure will likely have a lasting impact on international peace. Notably, the international aspect of TJ is far less frequently considered in the normative literature. ${ }^{19}$ From an international perspective, TJ carries its own set of normative questions, chiefly that of which ideals and principles should guide the foreign policy of international actors when confronting DDS. Ideally, it should help to balance the important goals of aiding societies in transition and maintaining an appropriate level of respect for their right to political self-determination.

In articulating a normative conception of TJ, a further obstacle lies in defining precisely what such societies are transitioning to, with some scholars and practitioners investigating $\mathrm{TJ}$ in the ambit of transitions to democracy and others considering it in the context of regime change more generally. ${ }^{20}$ What remains constant is that matters of $\mathrm{TJ}$ arise in societies where even the very minimum conditions for reciprocity are absent. Thus, the pragmatic issue at hand becomes the (re)instatement of these circumstances on which a society may be built. The normative component of TJ must therefore incorporate the conditions whereby the members of DDS can come to recognize each other as co-participants in a shared political project which displays at least weak reciprocity. ${ }^{21}$

TJ requires a normative framework suited for the special non-ideal circumstances of DDS, which is able to intertwine the domestic and international dimensions. Thinking normatively about TJ should allow us to set the appropriate limits between individual vs. collective and domestic vs. international dimensions. It must be prescriptive, so as to provide actual guidance in the non-ideal circumstances of DDS. It should seek to identify norms that reflect a shared understanding of human

\footnotetext{
${ }^{18}$ Taylor 2004, 23.

${ }^{19}$ One promising attempt from the empirical literature to problematize TJ as a 'globalized' phenomenon has been put forward by Teitel 2014.

${ }^{20}$ Examples of the first case are Mihai 2016 and Murphy 2017, while an example of the second is Teitel 2014.

${ }^{21}$ The idea of reciprocity is central to several normative accounts of reconciliation, see for example Verdeja 2017, Murphy 2010 and Gutmann and Thompson 2000. Yet, in these works, this idea is only considered from a domestic perspective. We instead propose an account of TJ that introduces a twofold standard (domestic and international) for reciprocity. TJ should aim to foster those domestic arrangements which support the emergence of, at least, weak reciprocity, while enabling DDS to act with full reciprocity in their interactions with other societies.
} 
rights standards as this is a necessary, if not always sufficient, ${ }^{22}$ institutional pre-condition for social cooperation. At the same time, we must be aware of the particularity of historical, cultural, and ethical contexts, so that forms of social cooperation might emerge from within DDS to sustain the transition.

\section{TJ and democracy: a problematic nexus}

In the contemporary normative discourse on TJ, a clear bias supports a liberal democratic framework of normative assessment. ${ }^{23}$ Along with the protection of human rights, the promotion of democracy is generally taken to be the core normative aim of TJ. While some scholars have examined the conflicts that may arise between liberal democracy and certain features thought to be essential to TJ, ${ }^{24}$ few question the link outright. ${ }^{25}$

There are both empirical and normative reasons for the strong conceptual link between TJ and democracy. First, the historical-political context in which the branch of normative enquiry related to TJ developed is deeply bound up in the liberal peace-building agenda. TJ as a distinct field of research and action crystallized in the context of the fall of communism and the 'third wave' of democracy in Latin America and Eastern Europe. ${ }^{26}$ As the third wave spread around the globe in the 1990s, democracy promotion became the foreign policy gold-standard for thinking about how to facilitate political change in DDS. ${ }^{27}$ This paradigm is founded on the assumption that the surest way to secure both domestic and international peace is through the establishment of democracy. ${ }^{28}$ In political theory, this is what is referred to as the 'democratic peace thesis', which holds that mature democracies are less likely to go to war with one another because of several key features they possess. Among these are the accountability of leaders to the citizenry and the consequent propensity to conduct foreign affairs through diplomacy rather than force, as well as a free market which promotes willingness to participate in the global economy and tendency to abide by international rules. ${ }^{29}$

For many authors, however, the relationship between TJ and democracy goes beyond de facto historical connections and practical considerations and there are strong moral reasons to include democracy as a constitutive aim of TJ. Murphy, for example, argues that democracy, understood as 'a form of governance' centred

\footnotetext{
${ }^{22}$ Rawls 1999, 68; on this see also Audard 2007, 257.

${ }^{23}$ See, for instance, Gutmann and Thompson 2000; Crocker 2002; Dryzek 2005; Moellendorf 2007; Bashir 2012; De Greiff 2012; Mihai 2016; Murphy 2017.

${ }^{24}$ The idea of reconciliation that is at the core of TJ discourses has been described either as a political value compatible with liberal democracy (e.g. Moellendorf 2007; Murphy 2010; Gentile 2018a) or as a comprehensive ethical goal which is at odds with some core liberal tenets (e.g. Gutmann and Thompson 2000; Philpott 2012). Other works have critically examined the compatibility between the pursuit of reconciliation and different normative democratic frameworks, ranging from deliberative democracy (e.g. Crocker 2002; Dryzek 2005; Bashir 2012) to agonist models (Schaap 2006; Muldoon 2008).

${ }^{25}$ Although with exceptions (e.g. Sharp 2014 and 2013 and Sriram 2007). Notably, some works in the field of decolonial studies have pointed out that this nexus tacitly relies on a so-called 'liberal teleology' and thus tied to coloniality (see Park 2020, 262), so that the TJ project becomes necessarily a project of domination over colonized subjects.

${ }^{26}$ Teitel 2014.

${ }^{27}$ Carothers 2002, 6 .

${ }^{28}$ See, for instance, Paris 2004.

${ }^{29}$ See Doyle 1983a and 1983b, Diamond 1992 and Fukuyama and McFaul 2007-08.
} 
on an ideal of equality of all citizens, provides the only morally defensible framework for the account of societal transformation required for TJ. ${ }^{30}$ Mihai never questions that the commitment to equal respect and concern for all, ${ }^{31}$ typical of a normative account of constitutionalism, is the metric by which transitional processes are to be assessed. Similarly, De Greiff argues that democracy is one of the 'final aims' of TJ. ${ }^{32}$ Thus, a universal right to democracy, defended as either a universal human good or an instrumental value needed to protect other urgent rights, ${ }^{33}$ seems to work as a basic assumption in this literature.

Recently, empirical works and field research have problematized precisely this relationship between TJ and democracy. ${ }^{34}$ Yet, we believe that it is from within liberal normative theory that this link appears to be especially problematic. ${ }^{35}$ Although normative scholars in the field of TJ tend to conceive of democracy as a fundamental human right, in the literature on human rights this claim is controversial. ${ }^{36}$ The argument against a human right to democracy is most commonly levelled from the perspective of the 'political conception' of human rights, which see them as inseparable from their political role in the international order. ${ }^{37}$ The contemporary human rights practice, these authors argue, "has created a standard for international political legitimacy ${ }^{38}$ such that respecting the human rights of its citizens becomes a necessary condition for a polity to be recognized as a participating member of the international community. ${ }^{39}$ The violation of said rights warrants the interference of international actors, in the form of diplomatic pressures, sanctions, and even military intervention. Although widespread violations of negative liberties (freedom from torture e.g.) do seem to rise to a sufficient level of urgency to warrant the intervention of the international community, it is far more problematic to interfere in the sovereign affairs of a state to promote a particular form of political organization, that is, democracy. This later point is demonstrated by the backlash against the US invasion of Iraq in 2003, citing as one of its justifications the absence of democracy there.

Importantly, the political argument against a human right to democracy need not necessarily reject the fundamental interests that democracy is usually understood to protect. A universal human right to democracy entails not only a certain kind of institutional structure (regular free and fair elections, etc.) but also the existence of certain interests that the institutional structure ought to protect. ${ }^{40}$ Crucially, most authors who argue for a 'political conception' of human rights endorse the fundamental interests that democracy is usually claimed to promote (reciprocity,

\footnotetext{
${ }^{30}$ Murphy 2017, 36.

${ }^{33}$ See, for example, Christiano 2015.

${ }^{31}$ Mihai 2016, 31.

${ }^{32}$ De Greiff 2012, 52ff.

${ }^{34}$ Sriram 2007; Park 2020; Sharp 2013, 2014.

${ }^{35}$ In the decolonial literature on this topic (see Park 2020) it is often argued that the liberal normative component in TJ discourses is itself problematic, as it reveals a western-centric form of domination that should be abandoned in favour of more radical counterhegemonic energies (De Sousa Santos 2015). We in fact agree with this criticism to a certain extent but, as we show in this paper, we believe that when properly tempered with notions of toleration and pluralism, liberal democracy provides valuable insights that cannot be gained from deconstruction alone.

${ }^{36}$ Cohen 2004 and 2010; Bernstein 2006; Beitz 2009; Peter 2015.

${ }^{37}$ Reidy 2012; Peter 2015; Hanisch $2016 . \quad \quad{ }^{38}$ Peter 2015, 482.

${ }^{39}$ Hanisch 2016, 240.

${ }^{40}$ Beitz 2009, 175.
} 
a certain ability to meaningfully contribute to political life) while still allowing a margin of national discretion as to how those interests may best be protected. ${ }^{41}$

Despite the connection between TJ and democracy, there are several normative aspects of TJ which might lead us to question whether liberal democracy can even make a meaningful contribution to the topic. First, many core aspects of TJ contradict a long-standing tradition within liberal theory about the certainty of punishment for offenders and its neutral, non-metaphysical, understanding of politics. ${ }^{42}$ TRCs, for example, often employ a moral understanding of the law, where the aims of 'reconciliation' and forgiveness might take precedence over legal retribution. Second, the restorative account of justice, often implicit in TJ, tends to blur the lines between public and private, self and community. In some reconciliation mechanisms private or non-public reasons are employed to restore a sense of solidarity and social harmony. Famously, in South Africa's transition, Archbishop Tutu took a leading role in associating the work of the South African Truth and Reconciliation Commission with traditional values, notably the concept of Ubuntu, and Christian forgiveness. ${ }^{43}$ In the recent turn towards more local, community-based mechanisms of TJ, precolonial cultural values and traditional social norms, such as bashingantahe in Burundi, are increasingly influencing the way the transition processes take shape. ${ }^{44}$ However, this might seem to undermine precisely the form of neutrality that liberal democracy requires. This is what Gutman and Thompson have in mind when they observe that reconciliation is an 'illiberal aim' when it asks the whole society to endorse one single comprehensive view of social unity. ${ }^{45}$ Yet, some might wonder whether a process of reconciliation can ever be achieved in the absence of such a comprehensive view. Third, the standard by which we evaluate the normative legitimacy of democratic political authority presupposes citizens' willingness to endorse institutions and norms associated with this distinctive form of political authority. In other words, liberal legitimacy relies on a willing acceptance of democratic institutions, as citizens should feel that the law could have been co-authored by them, or at least someone like them. This type of legitimacy is the lynchpin of normative stability in a liberal society, as the interplay between the laws/institutions and the citizen-subjects/ co-authors should be mutually reinforcing over time. However, in DDS, these institutions might not only be missing, but when they exist, there might be a strong sense of detachment and distrust towards them. ${ }^{46}$ These circumstances endanger the possibility for these societies to be stable for the right reasons, as predicated by liberal democracy. ${ }^{47}$ Yet, as we show in this paper, this account of stability falls beyond the scope of TJ.

\section{TJ, liberal democracy, and stability}

DDS face a persistent challenge of balancing claims of justice with goals of peace and stability. In the aftermath of a violent conflict or a tumultuous regime change when a society's institutions are in shambles and its civil society torn apart, it is

\footnotetext{
${ }^{41}$ Idid., $174 . \quad{ }^{42}$ Philpott 2012.

${ }^{45}$ Gutmann and Thompson 2000, 32-33.

${ }^{43}$ Tutu 1999. $\quad{ }^{44}$ See Ingelaere and Kohlhagen 2012.
}

${ }^{47}$ Mihai 2016. 
nearly impossible to imagine that a conception of justice of the kind we might deem appropriate for a mature democracy could be applicable. Thus, it is widely acknowledged and accepted that given the special circumstances in DDS what full justice requires is necessarily constrained by practical considerations and political compromise. This seems to suggest that the aim of justice, understood in terms of values and ideals, and the practical goal of creating a stable order conflict with one another, and indeed there is a great deal of empirical scholarship addressing precisely this rift. $^{48}$

There are also various distinct positions on how, and the extent to which, practical considerations ought to delimit the conception of justice itself. For some scholars, a moral minimalism is all we can aim for in thorny scenarios of the sort we face in DDS. ${ }^{49}$ On this account, these special conditions force us to narrow the normative goals of the theory itself. This form of moral minimalism is contrasted by other, maximalist, accounts. For those who believe that democracy is both the aim and the metric for judging the transition, for example, the problem of TJ is that of determining whether and to what extent different measures can help or hinder in fulfilling this goal. In this context, Mihai suggests that the trade-off between stability and justice is a false dilemma. ${ }^{50}$ Criticisms of trials and other mechanisms which focus on victims presuppose a kind of pragmatism, based on consequentialist considerations, that allow for only a 'narrow account of democracy' ${ }^{51}$ In contrast, she argues for a non-instrumental value of these 'hard' TJ mechanisms, which are needed in order to channel the negative emotions and resentment that permeate DDS in a positive direction so that they may actually come to sustain a democratic political culture. $^{52}$ On this account, the issue of stability is therefore entirely framed in terms of liberal democratic legitimacy.

Thus, the trade-off between stability, understood as the feasibility of the overall transitional project, and justice, understood as a set of values or ideals, ${ }^{53}$ is replaced by a different moral concern, one which questions the overall desirability of the TJ process. To be morally defensible, a normative account of TJ ought to disclose an understanding of justice, in defining the relations of members of a political community, that is reflected by their capacity to endorse that view. However, the very idea of 'transition' also matters from a moral point of view. It entails the fact that 'a community has a normative aspiration transforming itself (...) but has not yet achieved and is in fact not certain to achieve that aspiration'. ${ }^{54}$ Building on these premises, we present a normative rationale for TJ, which incorporates the actual circumstances of DDS and considers their implications at both the domestic and international levels. This account advocates an understanding of justice which is minimal in a different sense from what we called earlier 'moral minimalism'. Here, a minimal view of political morality which should inform TJ is meant to guarantee not only that there is consistency between the special circumstances of DDS and justice itself but also that this view is constrained by international toleration.

The approach we advocate therefore argues that practical and normative aspects are not just mutually supportive - as other accounts acknowledge - rather they

\footnotetext{
${ }^{48}$ See, for instance, Leebaw 2008; Olsen et al. 2010.

${ }^{50}$ Mihai 2016, $29 . \quad{ }^{51}$ Ibid., $30 . \quad{ }^{52}$ Ibid., 31.

${ }^{49}$ See, for instance Barghava 2000.

${ }^{53}$ Olsen et al. $2010 . \quad{ }^{54}$ Murphy 2017, 36.
} 
should be thought of as two sides of the same coin. Building on a chiefly normative idea of stability, we endorse the intrinsic value of certain fundamental interests commonly associated with political liberal justice, namely the ability to meaningfully participate in the construction of the political reality and to be subject to only those institutional arrangements that one could reasonably accept, while allowing for the possibility that there could be a degree of societal variation in the institutional arrangements best suited to realize those interests.

\section{Two dimensions of normative stability}

In this paper, we maintain that a normative theory of TJ should be able to acknowledge the different scopes of the liberal democratic ideal of stability: domestic and international. Rawls' political framework is uniquely equipped to recognize such a difference and takes seriously the normative implications that accompany it. It is our contention that the kind of normative stability DDS should aim to and which should guide the transition itself is one that enables these societies to become members, on equal standing, of a just international society, without undermining their internal capacity to define their own political and economic organization which might not satisfy the account of justice required for liberal democracy to obtain domestically. ${ }^{55}$ This task compels us to rethink the suitability of Rawls' theory in the context of TJ.

Despite rare exceptions, ${ }^{56}$ no sustained attempt has been made to investigate TJ in a Rawlsian perspective. There might be at least two reasons for disregarding Rawls' framework as appropriate for TJ. First, the very non-ideal circumstances of DDS seem to present insurmountable obstacles for the degree of abstraction typical of Rawls' theory. In other words, if we want to tackle actual political issues occurring in DDS, we need another, context-sensitive, perspective from which to evaluate the norms involved. Yet, Rawls himself recognizes the relevance of actual circumstances for realizing even a general ideal of political justice. ${ }^{57}$ Furthermore, he shows how certain ideal assumptions - that a well-ordered society is possible and can be stable for the right reasons - are vital to the overall feasibility of a liberal democratic project. $^{58}$ Famously, in connection with the case of the Weimar Republic, Rawls shows that its failure was largely due to the lack of faith in the ideal project of liberal democracy, rather than to the absence of the practical (institutional) conditions for it. ${ }^{59}$

Second, there is the obvious reason that he never explicitly mentions TJ matters in his work. It is, however, important to stress that both Political Liberalism and The Law of Peoples (hereafter, Peoples) contain elements that are pertinent to certain important features of TJ; all of them related to the relationship between ideal and non-ideal theory. When considering the limits of public reason, Rawls suggests that both the struggle of abolitionists and the civil rights movement led by M. L. King were necessary to establish the conditions for the transition of a non-well-ordered society, such as the USA under segregation, to a reasonably

\footnotetext{
${ }^{55}$ Bernstein $(2006,288 \mathrm{ff})$ suggests a similar view when she distinguishes between internal and external perspectives on legitimacy.

${ }^{58}$ Rawls 1996, liix.

${ }^{56}$ E.g. Moellendorf 2007; Gentile 2018a.

${ }^{59}$ Ibid., lix; see also Audard 2007, 194-5 and Gentile 2018a, 232.
} 
just political order. ${ }^{60}$ Furthermore, the non-ideal section of Peoples deals extensively with 'questions of transition', ${ }^{61}$ as we shall see later.

It is our contention that Rawls' sophisticated conception of toleration might help in considering the special case of DDS without imposing a particular view of political morality on the transition process itself. The significance of Rawls' contribution is especially useful as it pertains to the notion of normative stability. While stability played an important role in A Theory of Justice, in later works it becomes the central motivating philosophical problem. ${ }^{62}$ In his 'political turn', Rawls is unsatisfied with that view of stability, which entailed a congruence between the right and the good, ${ }^{63}$ as it conflicted with the important fact that liberal institutions foster a plurality of reasonable worldviews. Now, the principle of liberal legitimacy is the guarantee for the stability 'for the right reasons' under circumstances of persistent disagreement about the good. ${ }^{64}$ This view introduces a further dimension which transcends citizens' internal motivation to endorse justice. In his words 'stability involves two questions: the first is whether people who grow up under just institutions (as the political conception defines them) acquire a normally sufficient sense of justice so that they generally comply with those institutions. The second question is whether in view of the general facts that characterize a democracy's public political culture, and in particular the fact of reasonable pluralism, the political conception can be the focus of an overlapping consensus'. ${ }^{65}$ For political liberalism both questions are important to guarantee the stability of the shared conception of political authority. Although the first question is still focused on the moral psychology behind citizens' internalization of the principles of justice, the second entails a new, intersubjective dimension of stability that was absent in the first formulation. In a scenario in which we no longer assume that stability is based on congruence and we recognize the fact of reasonable pluralism, the problem of assurance comes into play and the aim of stability is that of reciprocally recognizing the equal role of our fellow citizens in the construction of a shared moral political horizon.

This new idea of stability is central to Rawls' analysis of justice in international relations. ${ }^{66}$ In Peoples, he clarifies that the theory 'is developed within political liberalism and is an extension of a liberal conception of justice for a domestic regime to a Society of Peoples' (Rawls 1999, 9). Therefore, the 'realistic utopia' developed in this book is meant to guarantee stability for the right reasons (Rawls 1999, 44ff) in a context characterized by a form of pluralism even more pronounced than what we find in a domestic case. Essential to this project however is that 'well-ordered peoples' are able to support an extended view of toleration. One which entails the mutual recognition of liberal peoples and nonliberal regimes, which he calls 'decent peoples' ${ }^{67}$ For Rawls, both kinds of political system might be able to endorse 'for the right reasons' the principles of justice that ought to govern the relations among

\footnotetext{
${ }^{60}$ Rawls 1996, 250-1; see also Gentile 2018b.

${ }^{61}$ Rawls 1999, 90.

${ }^{62}$ Rawls 1996, xv.

${ }^{63} \mathrm{Ibid}$., xvi; on this point see also Weithman 2016, 98ff and Reidy 2017, 368-9.

${ }^{64}$ Ibid., xxxix and xl.

${ }^{65}$ Ibid., 141.

${ }^{66}$ Reidy 2017, 363 and 378ff.

${ }^{67} \mathrm{~A}$ decent society is one in which basic human rights are endorsed and meets certain internal and external conditions. Domestically, its legal system must contain a decent consultation hierarchy which guarantees that the society's shared end is fulfilled, see Rawls 1999, 71. Internationally, it must act in support of international peace. A decent political regime of this sort, albeit not strictly liberal, should be respected internationally.
} 
them. Such principles are based on generally recognized norms in International Law, including self-determination, pacta sunt servanda, non-aggression and respect for a conception of human rights to be broadly interpreted. Importantly, norms which might be termed transitional, as they relate to issues which occur in nonideal circumstances, play a central role in guaranteeing the normative stability of international toleration. Rawls believes that constituent peoples would also reasonably agree on those principles that are meant to preserve such a form of stability and which include the norms of Just War and - what he calls - the 'duty of assistance' $^{68}$

Therefore, stability shapes the form that justice should take both domestically and internationally. It tells us that, domestically, the problem of justice is that of committing citizens, who reasonably disagree on metaphysical grounds, to the idea that their individual ends might be not only compatible with but even supported by a shared view of liberal democratic political morality. Furthermore, it asks well-ordered peoples, either liberal or decent, in the international realm to recognize that, given the degree of political diversity, ${ }^{69}$ the terms that should specify the social cooperation among them should be narrower than what full justice requires in each domestic society. ${ }^{70}$ Importantly, the normative stability of international toleration requires that certain actions be taken in order to cope with cases of non-compliance. Here, different principles reflect different kinds of noncompliance. Rawls distinguishes between regimes which refuse to comply with the law of peoples and, therefore, are aggressive towards other societies or violate human rights internally - outlaw states ${ }^{71}$ - from those societies which are unable to comply due to some 'unfavourable' historical, social, or economic conditions burdened societies. $^{72}$ Thus, to secure the legitimacy of the international order, the law of peoples has the twofold role of containing outlaw states and of supporting the transition of burdened societies to well-ordered regimes, either liberal or decent. Still, steps must be taken from within these societies to be recognized as members in good standing of the society of peoples.

Rawls' political turn and its further elaboration in Peoples help us to distinguish between two levels of analysis of justice. The international level, which derives normative authority from international law standards, is complemented by the domestic level of well-orderedness. Rawls argues that we ought to recognize the moral

\footnotetext{
${ }^{68}$ Ibid., 39, 106-8.

${ }^{69}$ For Reidy $(2021,21)$ the problem of Peoples is to address the issue of reasonable pluralism 'as exogenous source of potential instability' to liberal democracy.

${ }^{70}$ It would be a mistake to believe that the limitations on the shared view of international justice depend on the inclusion of decent peoples. On the contrary, Rawls believes that the degree of diversity among liberal peoples would bring these regimes to endorse a limited list of principles of right conduct in the international realm, while they would refuse to commit to a more robust view of liberal justice (Reidy 2004, 303). Thus, although the selected principles reflect what in the first-place free liberal peoples would choose, Rawls believes the same principles could also be endorsed by other nonliberal, yet decent, peoples (Mandle 2020, 376).

${ }^{71}$ Rawls 1999, 90ff

${ }^{72} \mathrm{Ibid}$., 4, 63 and 92, however, introduces a third case of partial compliance, which he calls 'benevolent absolutism'. As a political regime, benevolent absolutism does not fulfil both domestic and international requirements necessary for international legitimacy. This is a case of a political system that satisfies the external constraints for international legitimacy, such as respect for human rights and non-aggressiveness, however it is internally unreasonable as a 'decent' mechanism of consultation is lacking.
} 
status of two kinds of well-ordered regimes. ${ }^{73}$ Yet, while the ideas of wellorderedness and liberal legitimacy coincide domestically in the case of liberal regimes, decent peoples are not internally legitimate in the same way liberal peoples are. $^{74}$ Starting from the very idea of decency, therefore, this account sheds light on a new way of constructing the stability, legitimacy, and well-orderedness nexus. Although Rawls' extension of principled toleration to decent peoples has been strongly criticized in the literature, ${ }^{75}$ recent work aimed at reconsidering his view has clarified precisely this nexus. ${ }^{76}$

Internationally, Rawls posits a baseline conception of legitimacy which is compatible with the recognition of the prima facie legitimacy, or in his words 'wellorderedness', of certain decent cooperative systems that are either nonliberal or nondemocratic (or both). ${ }^{77}$ Such a conception entails two conditions. First, the regime in question must be based on some form of social cooperation regulated, at least, by weak reciprocity. ${ }^{78}$ Second, its institutions must generate obligations that have a "prima facie moral force ${ }^{79}$ for its subjects. When these two are met this fact matters from a normative viewpoint. Admittedly, Rawls never argues that decent well-ordered peoples are internally stable for the right reasons. ${ }^{80} \mathrm{We}$ may nonetheless concede that some form of normative stability is in place as their 'decent' institutions are morally meaningful for those subject to them. ${ }^{81}$ Therefore, internal well-orderedness along with their capacity to comply with the international law standards is what shapes their distinctive moral status and secures their role as bona fide members of the international society of peoples. ${ }^{82}$

We believe that both levels, external legitimacy (internationally) and wellorderedness (domestically), are important in the field of TJ as they provide a context-sensitive understanding of transitional processes. ${ }^{83}$ This view undergirds the weak universality ${ }^{84}$ necessary for addressing the international aspect of the transition, while allowing us to take seriously the particular social and political situation of each society. For Rawls a variety of well-ordered societies, not necessarily liberal, might well emerge internationally and they ought to be recognized as co-participants in the society of people. Thus, a balance must be struck between

\footnotetext{
${ }^{73}$ For an illuminating discussion on the differences between well-ordered peoples and the nature of decent peoples' moral status see Reidy 2021, 22-24.

${ }^{74}$ Ibid., 29.

${ }^{75}$ Criticisms have been raised from both cosmopolitan (e.g. Tan 1998; Beitz 2000) and statist (e.g. Nagel 2005) perspectives.

${ }^{76}$ See, especially, Bernstein 2006; Reidy 2007, 2017 and 2021 and Mandle 2020. In this paper, we depart from these works to show that Rawls' notion of international toleration and its implications for nonliberal 'decent' societies might provide an important contribution to the normative debate on TJ.

${ }^{77}$ Reidy 2007, 273.

${ }^{78}$ As Reidy (Ibid., 277) emphasizes internally decent peoples do not honour reciprocity 'in justification' but just what he calls 'reciprocity in interests' meaning the form of cooperative relationship emerging 'between persons understood, (...), to stand before the body politic not as free equals but as always already situated by group membership and obligations'. $\quad{ }^{79}$ Reidy 2021, $24 . \quad{ }^{80}$ Ibid., 29.

${ }^{81}$ See also Reidy $(2017,387)$, who argues that there is no 'apriori reason' for excluding that a form of stability is in place.

${ }^{82}$ Reidy 2021, 30.

${ }^{83}$ Several readers emphasise that in Peoples Rawls expresses a 'communitarian' character (see Williams 2014, 333) or in Audard's $(2007,254)$ words, a kind of social holism.

${ }^{84}$ Rawls $(1999,85-86)$ defines his own view as 'universal in reach'.
} 
a commitment to international law standards and respect for the diversity of world political cultures.

\section{DDS as a threat to international stability: a special case of burdened societies}

Rawls' realistic utopia suggests that the form of justice, which better fits the plural character of the international realm, should be able to combine the dual aim of feasibility and utopianism, each necessary to the other, to promote different kinds of domestic well-orderedness compatible with a form of international peace that is stable for the right reasons. We believe that features of a realistic utopia should be taken seriously when considering TJ. Here, the idea of international stability should be seen as crucially dependent on a degree of autonomy with respect to the political organization of given societies and introduces a different interpretation of the so-called 'democratic peace thesis'. This view does not necessarily entail what Audard $(2006,71)$ calls a 'holistic conception of peace' as opposed to a more ambitious moral aim of achieving international justice. As we understand Rawls' project, the two things need not be at odds. ${ }^{85}$ What some critics of Rawls, especially Audard, seem to deny is the very possibility that a society of peoples so designed could be effectively regulated by full reciprocity. ${ }^{86}$ Our reading of Peoples, instead, suggests that a lack of full reciprocity domestically (as is the case in decent societies) does not preclude the possibility of this type of reciprocity among peoples and therefore stability for the right reasons at the international level.

At the core of this account of democratic peace is an extended idea of toleration such that decent nonliberal regimes must be considered as bona fide constituent members of a peaceful international society. ${ }^{87}$ As we argued above, decent societies are well-ordered to the extent required for justice to obtain internationally. Decent regimes might not be governed by reasonable conceptions of constitutionalism. Also, they might be regulated by associational or community-based forms of representation, rather than the one-person-one-vote standard. ${ }^{8}$ Yet, as long as these societies' institutional architecture is grounded in a reasonable idea of the $\operatorname{good}^{89}$ and its laws and decisions have a force that is morally meaningful for those subject to that (decent) institutional structure, we cannot exclude that a form of reasonably stable attachment to it might emerge from within. ${ }^{90}$

Coming back to the case of DDS, certain circumstances obstruct these societies' transition to even decent regimes. From this perspective, DDS might be considered as a special case of what Rawls calls burdened societies. Rawls believes that societies troubled by adverse conditions are dangerous for the overall sustained support of an international compact based on international law standards. ${ }^{91}$ The unfortunate circumstances Rawls has in mind are historical, social, and economic

\footnotetext{
${ }^{85}$ As Williams $(2011,164)$ suggests, this view not only sustains peace but also promotes international justice.

${ }^{87}$ See also Doyle 2006.

${ }^{86}$ Meaning that it is both 'in interests' and 'in justification', see Reidy 2007.

${ }^{88}$ Rawls 1999, 73.

${ }^{89}$ Ibid., 74.

${ }^{90}$ In our view, this is where the difference between a 'decent consultation hierarchy' and 'benevolent absolutism' lies: the latter is dependent on the ruler for their continued stability and therefore envisages a mere system of 'coordination' (Reidy 2021, 37), whereas decent societies' stability is dependent on the weak reciprocity produced by its laws and institutions (Ibid., 44).

${ }^{91}$ Audard 2007, 244.
} 
in nature. ${ }^{92}$ At least, two of such circumstances matter in DDS, relating to specific social and historical contingencies which endanger the possibility of these societies becoming well-ordered. First, DDS face social and cultural conditions that might seem to preclude the possibility of the development of decent institutions due to the residual values (typically unreasonable) of the previous regime or state of affairs, such as racist rules, ethnic or religious tensions, prejudices or, finally, authoritarian political leanings. Second, these societies exhibit historical conditions, such as structural economic injustice and the legacy of past gross abuses which deeply challenge the possibility for social cohesion required for even a decent scheme of social cooperation. In these contexts, widespread feelings of resentment and distrust, towards not only fellow citizens but also the institutions of government, might manifest in a general lack of political will.

Famously, Rawls suggests that the international community of well-ordered societies should support the transition of burdened societies through the duty of assistance. ${ }^{93}$ The latter is to be understood not only in terms of economic support but should be aimed at helping to build well-ordered institutions. ${ }^{94}$ Notably, Rawls argues that 'what must be realised is that merely dispensing funds will not suffice to rectify basic social and political injustices (though money is often essential) ${ }^{95}$ The duty of assistance must be aimed at helping burdened societies rebuild their institutional structure so that they may 'reasonably and rationally ${ }^{96}$ manage their affairs and eventually become members in good standing of the Society of Peoples. Thus, the duty of assistance has a 'cut-off point' as far as it ceases to exist when the burdened society in question has become well-ordered, either as a liberal or a decent regime. Importantly, the duty of assistance must be carried out without undermining a society's own dominant culture. ${ }^{97}$ Human rights play an integral role in the way the duty of assistance is understood, insofar as respect for international law standards constitutes the threshold condition for people to be considered externally legitimate. ${ }^{98}$

However, Rawls warns that the aim of the transition is not fulfilled unless burdened societies' institutions reach at least a level of decency. As we suggested above, this entails both internal and external requirements. Thus, the duty of well-ordered societies to assist in achieving these goals needs to be supported by a genuine internal effort, so that the newly emerged well-ordered institutions are effectively endorsed by the population. The special social and historical circumstances of DDS require that external incentives and internal efforts are combined to make the transition at least conceivable. This is where we locate TJ mechanisms and policies. As Murphy notes, in order to understand whether different TJ means rightly respond to the demands of justice emerging in DDS, we should first understand 'what justice requires'99 precisely in these societies. Given the special circumstances of DDS, the form of disagreement, which characterizes individuals' judgements about the appropriateness of competing TJ mechanisms, not only reflects a conflict about their moral justification but entails different understandings of what is

\footnotetext{
${ }^{92}$ See also Fuller 2012, 372.

${ }^{93}$ Rawls 1999, 118. Here Rawls defines it as a 'principle of transition'.

${ }^{94}$ See also Williams 2014, 335.

${ }^{95}$ Rawls 1999, 108-9.

${ }^{96}$ Ibid., 111. ${ }^{97}$ Ibid.

${ }^{98}$ Bernstein 2006, $288 \mathrm{ff}$. ${ }^{99}$ Murphy 2017, 6.
} 
morally meaningful for them. This paper suggests that a minimal political morality, which is supported internationally, should guide the process of transition from such non-ideal circumstances to an ideal of well-orderedness, without undermining these societies' political autonomy. ${ }^{100}$

The twofold aim of TJ suggests a rationale for an approach which combines the objectives of external legitimacy (internationally) and well-orderedness (domestically). The duty of assisting DDS might entail support in prosecuting high-ranking perpetrators as well as in providing material and political support in developing other domestic means aimed at reconciliation. The latter might range from TRCs, memorials, forms of compensation for victims, to forms of reintegration of former oppressors. However, they might well include more comprehensive, community-based forms of restorative justice as well as mechanisms to redress socio-economic inequalities. External support should not undermine, but rather reinforce, DDS' ability to create a ground for full self-determination. Therefore, domestic political efforts in dealing with the past and in building weak reciprocity should prevail. The approach we propose is characterized by a normative division of labour, so to speak, between international and domestic political communities. Traditional TJ mechanisms (trials and TRCs) which reflect the international commitment to endorse basic human rights should be complemented by other means, aimed at fostering weak reciprocity. These, instead, reflect a commitment to the principle of self-determination.

\section{A metric for real-world instances of normative uncertainty}

The minimal conception of TJ, presented in this paper, suggests that the international community has a duty to assist DDS, understood as a special case of burdened societies, in their transitions. Yet, this support should not undermine the ability of these societies to deal with the past and to find autonomous ways to organize their political and economic structure for the future. ${ }^{101}$ As the fourth generation of TJ scholarship has highlighted, we should not condemn wholesale those practices which do not fit the liberal paradigm, nor should we uncritically accept all that is 'local' just because it is such. ${ }^{102}$ Also, it suggests that the standard debate on $\mathrm{TJ}$ must be complimented by an account aimed at redressing those adverse socioeconomic conditions that affect transitional situations. ${ }^{103}$ We believe that these concerns are well captured by our minimal conception. This account, developed in the spirit of political liberalism, is based on an idea of assistance which, albeit quite extended, ${ }^{104}$ refuses forms of paternalism. In our view, liberal democracy itself should not be the aim of TJ. Rather, TJ practices and mechanisms should aim at fostering the political autonomy of the DDS in question.

\footnotetext{
${ }^{100}$ See Mandle 2020, 377.

${ }^{101}$ As Williams $(2014,336)$ has argued, the very idea of the duty of assistance is that the burdened society in question should 'be treated in the spirit of equality and reciprocity'.

${ }^{103}$ Ibid.

${ }^{104}$ Although our proposal to understand the duty of assistance in the context of $\mathrm{TJ}$ is original, this reading entailing the most progressive approach to state-building compatible with Rawls's anti-paternalism - is largely supported in the literature. Williams $(2011,3)$, for example, holds that the duty of assistance is aimed at ensuring that these societies 'build up a minimal capability, which should qualify them for membership of the "Society of Peoples"'.
} 
This view is designed to provide a normative metric to determine when certain measures are of such critical importance that they should take precedence even when they oppose our expectations in terms of democratic transition. The first step in normative evaluation should assess whether a given component of the TJ process might contribute to the construction of institutions, which support weak reciprocity. The second step should weigh the process against international law standards. We believe that certain urgent human rights - rights to bodily security, freedom from torture, etc. - necessary to attain even weak forms of reciprocity are of absolute priority. As is the case in Rawls' view, urgent human rights set the immovable limits of international toleration. Therefore, those mechanisms that address gross violations, such as courts and TRCs, should be granted for any credible normative theory of TJ. Yet, our metric comes into play to balance between the domestic and international dimensions and to determine which aspect should be given special consideration in particular situations. This includes the guarantee of what might be called an 'international social minimum ${ }^{\text {'105 }}$ needed for DDS to overcome deep political and social injustices, which prevent them from becoming full members of a just international society. Thus, as for the full scale of human rights, these are to be taken into consideration in the normative assessment, along with the first step, in a process of reflective equilibrium. It may very well be the case that, given the particular historical and cultural circumstances of a given local context, certain rights that are usually thought to be unquestionable according to the liberal schedule of rights - freedom of conscience, for example - might justifiably be relaxed. ${ }^{106}$ Other issues which are often overlooked in TJ processes - for example, socio-economic concerns - may instead take on heightened importance.

In what follows, we sketch two brief examples of scenarios in which our metric proves to be useful in providing the degree of context sensitivity required to approach DDS while still offering a principled normative guidance. Of course, it is beyond the scope of this paper to delve into these complex cases in a comprehensive manner. We intend this section only as a small window into how our theory might help in real-world instances of normative uncertainty.

\section{Traditional reintegration of female soldiers in Sierra Leone}

Let's consider the example of 'traditional reintegration' of former combatants into their prerecruitment communities in Sierra Leone. ${ }^{107}$ These processes, which are often orchestrated by INGOs, involve the consultation of community elders and forms of religious ritual of cleansing. Traditional reintegration is generally perpetrator-oriented, as former combatants, both male and female, absolve themselves by taking responsibility for their actions. ${ }^{108}$ Yet, the line between perpetrator and victim is blurred in the case of female soldiers. ${ }^{109}$ Women and girls assume many roles, from active combatants, cooks, caregivers, and nurses to forced

\footnotetext{
${ }^{105}$ Ibid., 56.

${ }^{106}$ Notably, Rawls (1999, 65 and n. 2) suggests that only a 'sufficient measure of freedom of conscience' should be met internationally, consistently with the hypothesis of including nonliberal decent societies as equals in the Society of Peoples. $\quad{ }^{107}$ Park 2010, 108. $\quad{ }^{108}$ Ibid. $\quad{ }^{109}$ Denov 2010.
} 
'wives' and sexual slaves. ${ }^{110}$ In the later cases, they experience 'unique forms of rejection and stigma' upon returning home. ${ }^{111}$ Thus, the traditional reintegration often takes on an entirely different meaning in the case of female combatants and is seen as 'cleansing' them from the sexual violence. ${ }^{112}$

While such a community-based mechanism for reintegration can be seen as an integral part of the TJ process in Sierra Leone, ${ }^{113}$ it is easy to see why the practice, when applied to women and girls, leads to a feeling of uneasiness. There is certainly an open question as to whether the practice reinforces gender inequalities, for example "by legitimizing the notion that rape victims are "unclean" or validating the stigma attached to victims who do not participate in the ritual. ${ }^{114}$ Yet, there is evidence to suggest that these practices are seen by those directly involved to bring about reconciliation between women and their communities. ${ }^{115}$

The elements of this practice which go against predominant Western conceptions of equality and democracy - the disputable treatment of women and the use of extra-legal and religious elements - do not immediately hinder the acceptability of traditional reintegration from the perspective of our minimal conception. Ideally, a comprehensive study of traditional reintegration of women and girls in Sierra Leone, including first-hand testimony from them, would help to determine the full extent to which these practices contribute to fostering the form of weak reciprocity we advocate in this paper.

\section{Socio-economic harms and TJ: the case of East Timor}

Let's now consider the case of East Timor, where the Commission for Reception, Truth and Reconciliation (CAVR) has been one of the few to consider socio-economic aspects as an integral part of its mandate. The commission's report included a detailed accounting of deaths due to hunger and illness, and a chapter on forced displacement and famine. ${ }^{116}$ It listed other violations of socio-economic rights including the degradation of the education system and the coffee-market-related harms. The CAVR's report serves as an important model for how the conception of TJ can be practically expanded. ${ }^{117}$ This case is important to demonstrate that the inclusion of socioeconomic issues in the context of TJ involves widening it even further to include the roles and responsibilities of international actors as well. As documented in the report, the country's once profitable coffee industry was a significant factor in Indonesia's initial occupation, as well as a continued means to inflict systematic harm on the Timorese population through market manipulation and systematic environmental degradation. ${ }^{118}$ In considering the central role of the coffee industry in motivating and prolonging the occupation and genocide, we are also forced to address the central role of the international community, including liberal democracies such as the USA and Australia, in supporting the occupation.

Socio-economic concerns are usually taken as a background issue in TJ. Yet, often social injustices and economic oppression cannot be easily disentangled from other forms of civil and political violence occurring in DDS. Also, these issues are deeply entrenched with the role and the greedy interests of foreign actors. This

\footnotetext{
${ }^{110}$ Fisher 2013,169. $\quad{ }^{111}$ Ibid., 166. $\quad{ }^{112}$ Park 2010, 110. $\quad{ }^{113}$ Ibid. $\quad{ }^{114}$ Ibid., $111 . \quad{ }^{115}$ Ibid.

${ }^{116}$ The CAVR's final report can be found at: https://reliefweb.int/report/timor-leste/chega-reportcommission-reception-truth-and-reconciliation-timor-leste.

${ }^{117}$ Nagy 2008.

${ }^{118}$ Ibid. 185.
} 
is perhaps the case in which our metric most explicitly offers normative guidance. In cases where calls to include redistribution or even radical economic reforms come from within DDS, our metric suggests that we ought to take seriously these claims while allowing for the greatest degree of autonomy for these societies in the determination of their economic affairs. Here, it is necessary to mediate between a narrow, strictly humanitarian account of TJ and another broad, overly demanding view of TJ, as the one grounded in democracy as both its aim and metric. Our minimal conception combines the priority of making the institutions of DDS able to affirm basic human rights while setting an international social minimum threshold in terms of socio-economic justice for these regimes to become well-ordered. Yet, it does not prescribe one single route to the form of development which ensures the transition.

In cases like that of East Timor, our minimal approach points to the duty of the international community to assist the Timorese people in their justice-seeking efforts by employing a broader notion of the violence that occurred there. A good starting point for this would be a deeper look into the CAVR's report and an investigation into the losses to the country's coffee sector. Given the findings, recommendations for reparations could be made, not only on behalf of Indonesia but other countries that played less direct roles in supporting the violence. This suggestion is entirely motivated by the aim of supporting the normative stability of the international order and, thus, can be framed in terms of the duty of assistance. The duty of assistance is universal in the sense that it applies to all countries equally to the extent that they are in the position to carry it out, regardless of any responsibility they might (directly or indirectly) have in creating the adverse circumstances of the burdened society. The motivating idea behind the duty of assistance is to create the institutional conditions in which the most broadly shared conception of justice may obtain. This in no way precludes the other types of relational duties that those responsible for burdening a society may have. We can very well imagine that part of the institutional support put in place by the duty of assistance could go to establishing tribunals to investigate the roles and responsibilities of international actors, such as the one demanded by the Timorese people. ${ }^{119}$

\section{Concluding remarks}

This paper has proposed a minimal conception of TJ grounded in Rawls' idea of stability for the right reasons, which is able to capture the discontinuity between domestic and international justice. This understanding of $\mathrm{TJ}$ allows us to frame the problem of stability emerging in DDS entirely in normative terms. This approach does not require us to resign to consequentialism or pure pragmatism when considering the stability of transitioning societies, nor to abandon the principles of liberal democracy all together. Rather, it provides a normative account for the non-ideal circumstances of our world and hopefully a foundation on which the political self-determination of individuals and peoples can flourish.

\footnotetext{
${ }^{119}$ The same point could be made more generally with reference to those responsible for the past colonial exploitation of the DDS in question. Although the duty of assistance is not theorised as depending on a form of historical injustice (as colonialism certainly is), it should be carried out by avoiding any form of paternalism and by treating DDS with reciprocity. The lack of both features did of course characterize the colonial past.
} 
Acknowledgements. The original idea of the paper was developed by Valentina Gentile during her stay at the University of Antwerp in 2018/2019 and is mostly based on her previous research on reconciling divided societies. Further insights and, especially, the international dimension have been explored by the two authors while teaching a course on Global Justice at LUISS University. Versions of the paper have been presented at the Departmental Research Seminar and at the International Research Workshop 'Transitional Justice and Democracy' both at LUISS University. We thank all the participants in both events. For their valuable comments we are thankful to Vittorio Bufacchi, Emanuela Ceva, Corrado Fumagalli, John Horton, Federica Liveriero, Hennie Lötter, Pietro Maffettone, Sebastiano Maffettone, Domenico Melidoro, Darrel Moellendorf, Leonardo Morlino, Colleen Murphy, Aakash Singh Rathore, Albert Weale, and Paul Weithman. Special thanks are owed to three anonymous reviewers and the editors of this Journal for their constructive and valuable feedback. The two authors equally contributed to writing this paper.

Conflict of interest. The authors declare none.

\section{References}

Audard, Catherine. 2006. "Cultural Imperialism and Democratic Peace." In Rawls. A Realistic Utopia, edited by Rex Martin and David A. Reidy, 59-73. Malden, MA: Blackwell Pub.

Audard, Catherine. 2007. John Rawls. Stocksfield: Acumen.

Barghava, Rajeev. 2000. "Restoring Decency to Barbaric Societies." In Truth v. Justice: The Morality of Truth Commissions, edited by Robert I. Rotberg and Dennis Thompson, 22-44. Princeton, NJ: Princeton University Press.

Bashir, Bashir. 2012. "Reconciling Historical Injustices: Deliberative Democracy and the Politics of Reconciliation.” Res Publica 18: 127-43.

Beitz, Charles. 2000. "Rawls's Law of Peoples.” Ethics, 110 (4): 669-96.

Beitz, Charles. 2009. The Idea of Human Rights. Oxford: Oxford University Press.

Bernstein, Alyssa R. 2006. “A Human Right to Democracy? Legitimacy and Intervention.” In Rawls' Law of Peoples. A Realistic Utopia, edited by Rex Martin and David A. Reidy, 278-98. Malden, MA: Blackwell Pub.

Carothers, Thomas. 2002. "The End of the Transition Paradigm." Journal of Democracy 13 (1): 5-21.

Chemhuru, Munamato. 2018. “African Communitarianism and Human Rights.” Theoria 65: 37-56.

Christiano, Thomas. 2015. "Self-determination and the Human Right to Democracy." In Philosophical Foundations of Human Rights, edited by Rowan Cruft, S. Matthew Liao, and Massimo Renzo, 459-80. Oxford: Oxford University Press.

Cohen, Joshua. 2004. “Minimalism about Human Rights: The Most We Can Hope For?” Journal of Political Philosophy 12 (2): 190-213.

Cohen, Joshua. 2010. The Arc of the Moral Universe, and Other Essays. Cambridge, MA: Harvard University Press.

Crocker, David. 2002. "Punishment, Reconciliation, and Democratic Deliberation.” Buffalo Criminal Law Review 5: 509-49.

Dahl, Robert A. 1956. A Preface to Democratic Theory. Chicago: University of Chicago Press.

De Greiff, Pablo. 2012. “Theorizing Transitional Justice.” Nomos 51: 31-77.

De Sousa Santos, Boaventura. 2015. If God Were A Human Rights Activist. Stanford, CA: Stanford University Press.

Denov, Myriam. 2010. Child Soldiers: Sierra Leone's Revolutionary United Front. Cambridge: Cambridge University Press.

Diamond, Larry. 1992. "Promoting Democracy." Foreign Policy 87: 25-46.

Doyle, Michael W. 1983a. "Kant, Liberal Legacies, and Foreign Affairs, Part I." Philosophy and Public Affairs 12, 205-35.

Doyle, Michael W. 1983b. "Kant, Liberal Legacies, and Foreign Affairs, Part II." Philosophy and Public Affairs 12, 323-53.

Doyle, Michael W. 2006. “One World, Many Peoples: International Justice in John Rawls's The Law of Peoples." Perspectives on Politics 4 (1): 109-20.

Dryzek, John. 2005. "Deliberative Democracy in Divided Societies: Alternatives to Agonism and Analgesia." Political Theory 33: 218-42. 
Fisher, Kirsten. 2013. Transitional Justice for Child Soldiers: Accountability and Social Reconstruction in Post-Conflict Contexts. Basingstoke: Palgrave Macmillan.

Fukuyama, Francis, and Michael McFaul. 2007-08. “Should Democracy Be Promoted or Demoted?” The Washington Quarterly 31: 1-24.

Fuller, Lisa L. 2012. "Burdened Societies and Transitional Justice." Ethical Theory and Moral Practice 15: 369-86.

Gentile, Valentina. 2018a. "From a Culture to Civility to Deliberative Reconciliation." Journal of Social Philosophy 49 (2): 229-51.

Gentile, Valentina. 2018b. "Rawls' Inclusivism and the Case of Religious Militants: A Reply to Weithman's Restrictive Inclusivism." Philosophy and Public Issues 8 (1): 13-33.

Guidance Note of the Secretary-General: United Nations Approach to Transitional Justice (2010) https:// www.un.org/ruleoflaw/files/TJ_Guidance_Note_March_2010FINAL.pdf.

Gutmann, Amy, and Thompson, Dennis. 2000. “The Moral Foundations of Truth Commissions.” In Truth v. Justice: The Morality of Truth Commissions, edited by Robert I. Rotberg and Dennis Thompson, 22-44. Princeton, NJ: Princeton University Press.

Hanisch, Christoph. 2016. "A Human Right to Democracy: For and Against." Saint Louis University Public Law Review 35 (2): 233-56.

Ingelaere, Bert, and Kohlhagen, Dominik. 2012. "Situating Social Imaginaries in Transitional Justice: The Bushingantahe in Burundi." The International Journal of Transitional Justice 6: 40-59.

Tan, Kok-Chor. 1998. "Liberal Toleration in Rawls's Law of Peoples." Ethics 108: 276-95.

Leebaw, Brownwyn A. (2008). "The Irreconcilable Goals of Transitional Justice." Human Rights Quarterly 30 (1): 95-118.

Mandle, Jon. 2020. "Tolerating Decent Societies." In John Rawls, edited by Jon Mandle and Sarah Roberts-Cady, 371-8. Oxford: Oxford University Press.

Mihai, Mihaela. 2016. Negative Emotions and Transitional Justice. New York: Columbia University Press. Moellendorf, Darrel. 2007. "Reconciliation as a Political Value." Journal of Social Philosophy 38: 205-21.

Muldoon, Paul. 2008. "The Very Basis of Civility: On Agonism, Conquest and Reconciliation." In The Politics of Reconciliation in Multicultural Societies, edited by Will Kymlicka and Bashir Bashir, 114-35. New York: Oxford University Press.

Murphy, Colleen. 2017. The Conceptual Foundation of Transitional Justice. Cambridge: Cambridge University Press.

Murphy, Collen. 2010. A Moral Theory of Political Reconciliation. Cambridge: Cambridge University Press. Nagel, Thomas. 2005. "The Problem of Global Justice." Philosophy and Public Affairs 33 (2): 113-47.

Nagy, Rosemary. 2008. "Transitional Justice as Global Project: Critical Reflections." Third World Quarterly 29 (2): 275-89.

Olsen, Tricia, Payne, Leigh, and Reiter, Andrew. 2010. "The Justice Balance: When Transitional Justice Improves Human Rights and Democracy." Human Rights Quarterly 32 (4): 980-1007.

Paris, Roland. 2004. At War's End. Building Peace after Civil Conflict. Cambridge: Cambridge University Press.

Park, Augustine S.J. 2010. "Community-Based Restorative Transitional Justice in Sierra Leone." Contemporary Justice Review 13 (1): 95-119.

Park, Augustine S.J. 2020. "Settler Colonialism, Decolonization and Radicalizing Transitional Justice." International Journal of Transitional Justice 14: 260-79.

Peter, Fabienne. 2015. “A Human Right to Democracy?" In Philosophical Foundations of Human Rights. Philosophical Foundations of law, edited by Rowan Cruft, Matthew Liao and Massimo Renzo, 481-91. Oxford: Oxford University Press.

Philpott, Daniel. 2012. Just and Unjust Peace: An Ethic of Political Reconciliation. Oxford: Oxford University Press.

Plattner, Marc F. 1999. "From Liberalism to Liberal Democracy." Journal of Democracy 10 (3): 121-34.

Rawls, John. 1996. Political Liberalism. New York: Columbia University Press.

Rawls, John. 1999. The Law of Peoples. Cambridge, MA: Harvard University Press.

Reidy, David A. 2004. "Rawls on International Justice. A Defence." Political Theory 32 (3): 291-319.

Reidy, David A. 2007. "Reciprocity and Reasonable Disagreement. From Liberal to Democratic Legitimacy." Philosophical Studies 132: 243-91.

Reidy, David A. 2012. "On the Human Right to Democracy: Searching for Sense Without Stilts." Journal of Social Philosophy 43: 177-203. 
Reidy, David A. 2017. "Moral Psychology, Stability and the Law of Peoples." Canadian Journal of Law \& Jurisprudence 30: 363-98.

Reidy, David A. 2021. "Rawls, Law-making and Liberal Democratic Toleration: From Theory to Political Liberalism to The Law of Peoples." Jurisprudence 12 (1): 17-46.

Rubli, Sandra. 2013. "(Re)Making the Social World: The Politics of Transitional Justice in Burundi." Africa Spectrum 48 (1): 3-24.

Schaap, Andrew. 2006. “Agonism in Divided Societies." Philosophy and Social Criticism 32: 255-77.

Sharp, Dustin N. 2013. "Interrogating the Peripheries: The Preoccupations of Fourth Generation Transitional Justice." Harvard Human Rights Journal 26: 149-78.

Sharp, Dustin N. 2014. "Emancipating Transitional Justice from the Bonds of the Paradigmatic Transition." International Journal of Transitional Justice 9 (1): 150-69.

Sriram, Chandra L. 2007. "Justice as Peace? Liberal Peacebuilding and Strategies of Transitional Justice." Global Society 21 (4): 579-91.

Taylor, Charles. 2004. Modern Social Imaginaries. Durham, NC: Duke University Press.

Teitel, Ruti. 2014. Globalizing Transitional Justice. Contemporary Essays. Oxford: Oxford University Press.

Tutu, Desmond. 1999. No Future without Forgiveness. New York: Doubleday.

Verdeja, Ernesto. 2017. "Political Reconciliation in Postcolonial Settler Societies." International Political Science Review 38 (2): 227-41.

Weithman, Paul. 2016. Rawls, Political Liberalism and Reasonable Faith. Cambridge: Cambridge University Press.

Williams, Huw L. 2011. On Rawls, Development and Global Justice. The Freedom of Peoples. Basingstoke: Palgrave Macmillan.

Williams, Huw L. 2014. "The Law of Peoples." In A Companion to Rawls, edited by John Mandle and David A. Reidy, 327-45. Malden, MA: Blackwell Pub.

Wingo, Ajume H. 2006. "Fellowship Associations as A Foundation for Liberal Democracy in Africa." In A Companion to African Philosophy, edited by Kwasi Wiredu, 450-9. Malden, MA: Blackwell Pub.

Cite this article: Gentile, V., Foster, M. 2022. "Towards a minimal conception of Transitional Justice." International Theory 14 (3), 503-525, doi:10.1017/S1752971921000269 